\title{
Evaluation of Kinetic and Equilibrium studies for Phytoremediation of Methylene Blue Dye (Triarylmethane) and Congo Red (Diazo) using Trachyspermum Ammi L.
}

\section{Navjeet Kaur}

Chittagong University of Engineering and Technology

jyotsna kaushal ( $\nabla$ jyotsna.kaushal@chitkara.edu.in )

Chitkara University https://orcid.org/0000-0002-0241-5627

Pooja Mahajan

Chitkara Institute of Engineering and Technology

\section{Research Article}

Keywords: Methylene Blue Dye, Congo Red dye, Phytoremediation, Kinetics, Adsorption

Posted Date: August 19th, 2021

DOl: https://doi.org/10.21203/rs.3.rs-746247/v1

License: (c) (i) This work is licensed under a Creative Commons Attribution 4.0 International License.

Read Full License 
Title: Evaluation of Kinetic and Equilibrium studies for Phytoremediation of Methylene blue dye (triarylmethane) and Congo red (Diazo) using Trachyspermum ammi L.

Navjeet Kaur ${ }^{1}$, Jyotsna Kaushal ${ }^{1 *}$ and Pooja Mahajan

4 Centre for Water Sciences, Chitkara University Institute of Engineering and Technology,

5 Chitkara University, Rajpura (140401) Punjab (INDIA)

*Corresponding author: Jyotsna Kaushal

7 Postal address: Centre for Water Sciences, Chitkara University Institute of Engineering and Technology,

8 Chitkara University, Rajpura (140401) Punjab (INDIA)

$9 \quad$ Email: jyotsna.kaushal@chitkara.edu.in

Contact Number: + 91-9914241124

\section{Abstract}

Phytoremediation developed as a green-clean, solar-driven and innovative technique for the eradication of contaminants from the environment from last two decades. In the present research work, phytoremediation potential of an ornamental plant Trachyspermum ammi L. (T. ammi) was examined for the removal of a triarylmethane-Methylene blue (MB) and di-azo-Congo red (CR) dye. The various parameters such as initial dye concentration, contact time, and $\mathrm{pH}$ were focused to explore the dye removal capability of $T$. ammi. The increase in initial dye concentration affects the decolorization potential of the T. ammi. The decolorization potential of $T$. ammi found to be reduced with enhancing the initial dye concentration of both the dyes. The plant achieved condition of equilibrium after the $40 \mathrm{~h}$ of contact time with both MB and CR dye. The favorable $\mathrm{pH}$ for T. ammi for the MB dye was observed as 5 while for $\mathrm{CR}$ dye was 6 . The kinetics of phytoremediation reaction with both MB and CR dyes were studied with help of pseudo-first order, pseudo-second order, and Elovich models and the results were well appropriated to pseudo-first order with the correlation value $R_{2} \geq 0.95$ for $M B$ and $R_{2} \geq 0.97$ for CR. The Langmuir and Freundlich isotherms studies of phytoremediation reaction found in favor of Freundlich equilibrium isotherm with correlation $\mathrm{R}_{2} \geq 0.99$ for both $\mathrm{MB}$ and $\mathrm{CR}$ dyes. The mechanism of $T$. ammi for removal of dyes was supported with the help of analytical techniques such as Fourier Transform-Infrared Spectroscopy (FTIR) and Scanning Electron Microscope (SEM). 
Synthetic dyes used in textile industry are mostly allergic, carcinogenic, and mutagenic in nature. Furthermore, if these dyes are discharged in wastewater as such in the water bodies, it resulted into a deadly threat to aquatic life such as fishes, microbes, and other creatures of water bodies (Konicki et al. 2013; Aljeboree et al. 2014). The dye contaminated water is also unsuitable for human consumption. Subsequently, their complete expulsion from textile wastewater is a matter of great concern for research community. Various physio-chemical techniques such as adsorption, photo catalysis, advanced oxidation, precipitation, coagulation, solvent extraction, membrane removal etc. were proposed in the literature to remove dyes from textile wastewater (Ahmad et al. 2015; Ali et al. 2018; Kang et al. 2019). But, these types of techniques have less productivity, costly and produce intermediate contaminants. Because to these issues, there are lot of significant methods to develop eco-friendly, cost effective and resourceful method for treatment of textile dyes wastewater (Ullah et al. 2020). Some researchers also proposed the use of enzymes and microbes such as bacteria and fungi as an eco-friendly approach but in actual practice, microbial administration appears to be quite difficult (Khandare and Govindwar 2015; Sarkar et al. 2017; Arfin et al. 2019). In last two decades, another clean-green innovative plant-based technique known as phytoremediation comes into view as an eco-friendly and cost-effective method for the removal of the contaminants from wastewater in contrast with physio-chemical and biological methods (enzymatic, microbial) etc (Kabra et al. 2013, Khandare and Govindwar 2015). Phytoremediation technology is the best suitable, accepted as natural and sustainable development strategies to change over contaminated areas into the fruitful one with use of different varieties of plants. In literature, aquatic plant species such as Azolla pinnata (Al-Baldawi et al. 2018), Chara vulgaris (Mahajan et al. 2019; Mahajan and Kaushal 2020), Lemna minor (Imron et al. 2019), Eichhornia crassipes (Tan et al. 2016; Sharma et al. 2021), Pistia stratiotes (Mahajan and Kaushal 2019; Ekanayake et al. 2021), Salvinia molesta (Kaushal and Mahajan, 2015; Al-Baldawi et al. 2020), Typha angustifolia (Chandanshive et al. 2017) are more focussed for the phytoremediation of dye wastewater due to their easy administration in aqueous form. Many terrestrial plants also proved their potential for dye removal due to the effective enzymatic system in their roots. As illustration, the ornamental flowering plant Blumea malcolmii was reported to degrade the Direct Red 5B with involvement of number of enzymes present in its roots (Kagalkar et al. 2009). Aster amellus, Portulaca grandiflora, Glandularia pulchella, Petunia grandiflora and Nopalea cochenillifera were some other terrestrial garden ornamental plant species reported for the degradation of Remazol Red, Navy Blue HE2R, Green HE4B, Brilliant Blue Green and Red HE7B respectively (Kabra et al. 2011; Khandare et al. 2011a, b; Kabra et al. 2011; Adhi et al. 2012). Recently, some other commonly grown ornamental plants such as Asparagus officinalis, Alcea rosea, and Bacopa monnieri plant species reported for remediation of hazardous azo dyes (Watharkar et al. 2018, Mahmoudabadi et al. 2019, Shanmugam et al. 2020). In the present study, Trachyspermum ammi ornamental plant species of Apiaceae family explored for the removal of dyes. Previously, T. ammi was reported for the removal of heavy metals from the soil (Javed et al. 2020). Revathi et al. 2018 utilised the biomass of leaves of T. ammi as an adsorbent for removal of Grey BL dye from aqueous solution. As per our knowledge, no work is reported in literature for removal of dyes from aqueous solution by T. ammi plant in the living state. Hence, the present study was planned to examine the phytoremediation ability of T. ammi plant for removal of two structurally different dyes, a diazo dye Congo Red (CR) and a triaryl methane dye Methylene Blue (MB) in aqueous form. To optimise the phytoremediation process, the effect of contact time, initial dye 
through study of kinetic and equilibrium isotherms. FTIR and SEM studies were also performed to support the dye removal mechanism of $T$. ammi plant.

\section{Material and methods}

\section{Synthetic dye Solution}

The two structurally different dyes, a triarylmethane dye, Methylene Blue (MB) and a diazo dye Congo Red (CR) were used in present research work (Fig. 1). The solid form of MB and CR dyes used in experimental work was in a high analytical grade and acquired from Merck Limited, Mumbai. The MB and CR dyes are soluble in double distilled water, so the stock solutions of both dyes were prepared in water. The various initial dye concentrations were prepared by diluting the stock solution to required extents.

\section{Plant collection and cultivation}

T. ammi plants (Fig. 2) of same size and growth were collected from the botanical garden of the Guru Nanak Dev University, Amritsar, Punjab (India). Initially, plants were gently washed under the tap water thoroughly to remove soil for 10-15 minutes and after that kept in distilled water for $24 \mathrm{~h}$ so that plants become free from any soil particles. Before experimentation, plants were grown in half-strength Hoagland nutrient solution for one week so that plants can adjust themselves as medium changes from soil to water (Leggett and Frere 1971). The growth of plants has been observed after one week. It has been observed that plants grow faster in aqueous medium with extensive growth of roots. Thereafter, plants were transferred into dye solution $(100 \mathrm{~mL})$ in the beakers with support system for phytoremediation experiment.

\section{Phytoremediation experiments}

The phytoremediation experiments were performed with different concentrations of dyes (10, 20, 30, 40 and 50 $\mathrm{mg} \mathrm{L}^{-1}$ ) of $\mathrm{MB}$ and $\mathrm{CR}$ dyes by using T. ammi. The progress of the phytoremediation experiment was analysed by measuring absorbance of dye solution with the help of Shimadzu-2550 UV-visible double beam spectrophotometer. The samples of dye solution up to $2 \mathrm{~mL}$ were taken every $8 \mathrm{~h}$ up to $40 \mathrm{~h}$ for measuring absorbance and then decolorization percentage was calculated as given below (Kabra et al. 2011):

$$
\text { Decolorization }(\%)=\frac{\text { Initial absorbance-Final absorbance }}{\text { Initial absorbance }} \times 100
$$

The quantity of dye removed by the $T$. ammi at any time is ' $\mathrm{q}_{\mathrm{t}}$ ' $\left(\mathrm{mg} \mathrm{g}^{-1}\right)$ and ' $\mathrm{q}_{\mathrm{e}}$ ' $\left(\mathrm{mg} \mathrm{g}^{-1}\right)$ at equilibrium determined from equations 2 and 3 respectively (Mahajan and Kaushal 2020):

$$
\begin{aligned}
& q_{t}=\frac{\left(C_{0}-C_{t}\right)}{W} \times v \\
& q_{e}=\frac{\left(C_{0}-C_{\mathrm{e}}\right)}{\mathrm{w}} \times v
\end{aligned}
$$

' $\mathrm{C}_{0}$ ' is the initial dye concentration, ' $\mathrm{C}_{\mathrm{t}}$ ' is the dye concentration any time ' $\mathrm{t}$ ' and ' $\mathrm{C}_{\mathrm{e}}$ ' is the equilibrium dye concentration in $\mathrm{mg} \mathrm{L}^{-1}$, ' $\mathrm{v}$ ' is the volume of the solution in $\mathrm{mL}$ and ' $\mathrm{w}$ ' is the weight of the plant in $\mathrm{g}$. The fresh weight of the plant is taken after drying several times in folds of filter paper.

\section{Kinetics and Equilibrium studies}


The kinetics of T. ammi for the removal of the MB and CR dyes was interpreted by using the pseudo-first order, pseudo-second order and Elovich models as demonstrated by equations 4, 5 and 6 respectively (Ahmed et al. 2014):

$\log \left(q_{e}-q_{t}\right)=\log q_{e}-K_{1} t$

$\frac{t}{q_{t}}=\frac{1}{K_{2} q_{e}^{2}}+\frac{1}{q_{e}} t$

$q_{t}=\frac{1}{\beta} \ln (\alpha \beta)+\frac{1}{\beta} \ln t$

where ' $\mathrm{K}_{1}$ ' and ' $\mathrm{K}_{2}$ ' are the rate constants for pseudo-first order and pseudo-second order, respectively. In eq. $6^{\prime} \alpha$ ' determine the chemisorption, and ' $\beta$ ' find out that how much adsorption takes place at adsorbent surface. The application and importance of suitability of the kinetic models to experiment data are predicted with the regression value $\left(\mathrm{R}^{2}\right)$ and standard deviation of normalized value $(\Delta \mathrm{qt} \%)$. The normalized standard deviation value is computed with following equation (Mahajan and Kaushal 2020):

$\Delta q_{t} \%=100 \frac{\sqrt{\sum\left|\frac{q_{\left.t(\text { exp })-q_{t(\text { theor })}\right)^{2}}}{q_{t(\text { exp })}}\right|}}{n-1}$

where $\mathrm{q}_{\mathrm{t}}(\exp )$ and $\mathrm{q}_{\mathrm{t}}$ (theory) are the practical and theoretical values of the amount of dye remediated from aqueous solution where "n" corresponds to the numeral count of experiment. The rationality of kinetics models is based upon the value of $\Delta \mathrm{q}_{\mathrm{t}} \%$. The lower is its value for the kinetic model, higher is the acceptability of the data for that model.

The equilibrium studies of phytoremediation reactions were determined with the help of Langmuir and Freundlich models represented by equations (8) and (9) respectively (Wang et al. 2018).

$\frac{C_{e}}{q_{e}}=\frac{1}{b Q_{0}}+\frac{1}{Q_{0}} C_{e}$

$\log q_{e}=\log k_{f}+\frac{1}{n} \log C_{e}$

The Langmuir adsorption constants ' $\mathrm{b}$ ' and ' $\mathrm{Q}_{0}$ ' were related to the high ability of adsorption of the dye at equilibrium and rate of adsorption correspondingly. The value ' $n$ ' finds the spontaneity in behaviour of dye molecules toward phytoremediation process in case of Freundlich adsorption isotherm, and ' $\mathrm{K}_{\mathrm{f}}$ ' is the adsorption capacity for the plant. The valuable Langmuir isotherm parameter ' $\mathrm{R}_{\mathrm{L}}$ ' is suggested for equilibrium parameter and determined by following equation (Mahajan and Kaushal 2020):

$R_{L}=\frac{1}{b+C_{o}}$

When there is irreversible process, the $\mathrm{R}_{\mathrm{L}}$ value corresponds to the zero, and it is for favourable conditions. The value becomes more than one for the unfavourable process (Kaur et al. 2015).

\section{Characterization techniques}

The root surface of $T$. ammi plant was evaluated by FTIR and SEM techniques. The FTIR of dried sample of $T$. ammi was examined before and after phytoremediation of both MB and CR dyes. The infrared spectra were taken with Agilent (CARRY-630) spectrophotometer with range of $400-4000 \mathrm{~cm}^{-1}$. The surface analysis of the $T$. ammi was examined with the help of scanning electron microscope (JEOL-JSM-6100 Ltd, Japan). T. ammi particles were placed on stubs and coated with gold foil by the gold- coating machine- JEOL-JSM-6100 Ltd, Japan.... 
141 T. ammi has shown the efficient removal of the MB and CR dyes up to $40 \mathrm{~h}$ and found to active after eliminating 142 the maximum percentage of the dyes. The equilibrium stage of experiment was achieved after $40 \mathrm{~h}$ and both MB 143 and CR dyes solution decolorised up to maximum extent. The different parameters, kinetics, and absorption mechanism of T. ammi have been detailed on the obtained results.

\section{Surface Characterisation of T. ammi roots}

146 To characterize the functional group present on T. ammi roots, its FTIR spectra was taken before and after phytoremediation of both MB and CR dyes. The FTIR spectra T. ammi roots before and after dye adsorption was shown in Fig. 3 and comparative interpretation of results of FTIR spectra was presented in Table 1. The FTIR spectra depicts the presence of functional groups such as phenolic and carboxyl group which is indicated in roots of T. ammi and these results agree with the previous spectra reported for T. ammi plant extract (Qamar et al. 2020). Mathew et al. 2008 also confirmed the presence of Thymol (2-isopropyl-5-methyl phenol) as main active constituent of T. ammi plant extract. It has been inferred in Fig. 3 that most of the FTIR peaks changes its position after the adsorption of dye due to interaction among functional group of dye and root. For instance, the FTIR spectrum for T. ammi exhibits a strong broad band at $3431 \mathrm{~cm}^{-1}$ assigned to the $\mathrm{O}-\mathrm{H}$ stretching vibration of phenolic group which on adsorption of MB and CR dye changes its position at $3364.4 \& 3371.4 \mathrm{~cm}^{-1}$ respectively and gets more broader due to extensive intermolecular H-bonding (Mahajan and Kaushal 2019). Similarly, peaks appear due to carbonyl group stretching $1248.7 \& 1036.2 \mathrm{~cm}^{-1}$ shifts their position and it has also been observed that the intensities of these peaks changed from strong to medium or weak. These results strongly recommended that functional group interaction plays an important role in adsorption of dyes from their solution by T. ammi plant roots. The feeble peaks appear at 1584, $1509 \& 1451 \mathrm{~cm}^{-1}$ (after MB adsorption) and 1653, $1507 \& 1458 \mathrm{~cm}^{-1}$ (after adsorption of CR dye) confirmed the adsorption of dye molecules. by roots of T. ammi during phytoremediation process. As SEM is one of the best technologies for the surface characterization of adsorbent, so surface analysis of $T$. ammi roots confirmed the absorption of dye by roots through phytoremediation process (Aljeboree et al. 2017). SEM of T. ammi roots is recorded for both before and after the phytoremediation experiment with MB and CR and results are presented in form SEM micrographs (Fig. 4). Fig. 4a, indicates the smooth surface having prominent pores in the fresh roots of $T$. ammi before phytoremediation process while Fig. $4 \mathrm{~b}$ and c the dye loaded surface of $T$. ammi roots. It has been clearly depicted from Fig. $4 \mathrm{~b}$ and $\mathrm{c}$ shows that surface of T. ammi roots is covered with MB and CR dyes, respectively. The SEM images of T. ammi roots show prominent colored marks which could be assumed as indication of adsorption of dyes by T. ammi roots acts as the adsorbent for removal of dyes from its solution during phytoremediation process (Qamar et al. 2020).

\section{Kinetic and equilibrium studies}

The kinetic studies of phytoremediation for different dyes in aqueous phase in living forms were suggested by 
phytoadsorption (Mosoarca et al. 2018; Saber et al. 2018; Mahajan and Kaushal 2019, 2020; Kaushal and Mahajan 2021). Therefore, the phytoremediation kinetics study of MB and CR dyes with the help of T. ammi was studied with pseudo-first order, pseudo-second order, and Elovich models. The kinetic graphs of various models at different concentrations of MB and CR dyes are shown in Fig. 5-7. The constants of kinetics and other used parameters determined from kinetic plots for MB and CR dye are presented in Table 2 and 3 respectively. Fig 5a$\mathrm{b}$ depicts the pseudo-first order straight-line graph with negative value of slope when $\log \left(\mathrm{q}_{\mathrm{e}}-\mathrm{q}_{\mathrm{t}}\right)$ against time ( $\left.\mathrm{t}\right)$ had plotted at various concentrations for T. ammi. Figure 6a- b depicted a linearized plot with the positive slop when $\mathrm{t} / \mathrm{qt}$ plotted versus " $\mathrm{t}$ " for pseudo-second order kinetic model and $\mathrm{k}_{2}$ and $\mathrm{q}_{\mathrm{e}}$ (theor) values are predicted with the help of intercept and slope respectively for different concentration for both the dyes. The Elovich constants $\alpha$ and $\beta$ has been determined by the slope and intercept, of the plot between $\mathrm{q}_{\mathrm{t}} \mathrm{vs} \ln \mathrm{t}$ depicted in Fig. 7a- b. From Table 2 and 3, it has been clearly depicted that $R_{1}^{2}$ values lies either above 0.90 or near to it for most of concentrations of both the dyes in case of pseudo-first order only in comparison to pseudo-second order and Elovich model. Moreover, $\mathrm{q}_{\mathrm{e}}$ (theor) values are for $T$. ammi are found to be more consistent to $\mathrm{q}_{\mathrm{e}}$ (exp) for pseudo-first order in case of both of dyes MB and CR while for pseudo-second order and Elovich model $\mathrm{q}_{\mathrm{e}}$ (theor) values are far

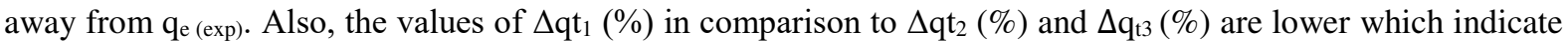
toward the acceptability of the data for pseudo-first order for both the dyes. Hence, the value of experimental data of the phytoremediation of MB and CR dyes by T. ammi showed better compliance with pseudo-first order. It has been also observed that when there is increase in the initial dye concentration then the rate constant $\left(\mathrm{k}_{1}\right.$ and $\mathrm{k}_{2}$ ) value decrease gradually for MB and CR dye removal by T. ammi (Table 2 and 3). There is probability of competition in co dye molecules to acquire available adsorbent sites on surface of plant. Hence, there is decrease in electrostatic interaction on increasing the initial dye concentration and the reduction in the dye interaction towards the plant surface. Therefore, chemisorption mechanism may restrict by the rate of the adsorption of MB and CR dyes by T. ammi (Sánchez-Galván et al. 2008). In Table 2, the value of constant $\beta$ has been decreased by the enhancement in the dye concentration which shows that the site of adsorption for MB and CR dye was low in value in the T. ammi surface and therefore, MB and CR uptake dyes by plant surface might occur through functional group interaction (Kaushal and Mahajan 2021). Additionally, the constant value $\alpha_{\mathrm{El}}$ decreased by the increase in initial dye concentration, which indicated that more than one mechanism which drives the phytoremediation process.

The equilibrium studies on phytoremediation were also work out by using the Langmuir and Freundlich adsorption isotherm. The monolayer adsorption is depicted by Langmuir isotherm with specific and uniform adsorption sites on the surface while Freundlich model is affected by the heterogeneous nature of surface sites (Hameed et al. 2007). The evaluation of regression coefficient $\left(\mathrm{R}^{2}\right)$ and other various constant values had been predicted by linear regression plot are presented in Table 4. The value of $\mathrm{R}^{2}$ Langmuir adsorption isotherm was found to be 0.987 and 0.983 for MB and $C R$ and the equilibrium constant $R_{L}$ value has been found to be decreases with increase in concentration. $R_{L}$ value was determined to be 0.0197 , and for $C R$ the value for $R_{L}$ is 0.0198 at 50 $\mathrm{mg} \mathrm{L}^{-1} \mathrm{MB}$ dye concentration, indicated that $\mathrm{MB}$ and $\mathrm{CR}$ dye adsorption by $T$. ammi is highly favorable in high concentration due to bonding between functional groups present on T. ammi root cells and dye molecules (MiHwa et al. 2010). The little bit better fitting of Freundlich model $\left(R^{2}=0.999\right)$ during the adsorption for $C R$ dye than for MB $\left(\mathrm{R}^{2}=0.990\right)$ on $T$. ammi which suggested the heterogenous nature of T. ammi surface (Table 4). As the value $1 / \mathrm{n}$ of Freundlich isotherm obtained to be lower than 1 , hence it has been predicting the surface with 

is chemical and if the value of $n$ comes more than unity then process is physical and favorable. The $1 / n$ value for of MB adsorption on the surface of $T$. ammi has been obtained to be 0.1784 , which determine the valuable adsorption of MB dye on the T. ammi surface (Fytianos et al. 2000) and for the CR dye value of $1 / \mathrm{n}$ was obtained as 0.3175 which is supportive adsorption at surface of $T$. ammi.

Impact of contact time, initial dye concentration, pH parameters on the adsorption capacity of phytoremediation of T. ammi

For examine the effect of time on increasing dye concentration on decolourisation percentage of T. ammi plants were dipped in $250 \mathrm{~mL}$ beaker containing $100 \mathrm{~mL}$ of MB and CR dye solutions containing 10, 20,30, 40 and 50 $\mathrm{mg} \mathrm{L}^{-1}$. The amount of dye removed by the plant was determined up to $40 \mathrm{~h}$ because maximum adsorption takes place up to $40 \mathrm{~h}$ and further no more adsorption observed. The rate of adsorption and decolourisation becomes high with increase in the time. The plot of amount of MB and CR dye adsorbed by plant as a function time is shown in Fig. 8 a and b respectively. Initially the rate of adsorption may be high due to proximity of the uncovered surface area of the adsorbents, however, it has been observed that the phytoremediation capacity of T. ammi to decolorise $\mathrm{MB}$ and $\mathrm{CR}$ dyes solution decreases with further increase in concentration. This is because of high concentration pores of adsorbent become blocked due to blockage of high concentration of adsorbate particles and rate of adsorption becomes decreases. These types of results were reported in research study of Glandularia pulchella for remediation of Green HE4B (sulphonated azo dye). The reduction in decolorization capacity might be toxic on plant system due to the influence of enhancing concentration which hinders the metabolism of plant, and thus, reduces the metabolic activity of the plant system (Kabra et al. 2011). The fast adsorption at initial phase of experiment is caused by the high amount of dye particles in the solution and large number of unoccupied sites available on plant which behaves as driving force for remediation process, while on last phase the driving force reduces. The decrease in the driving force could be due to saturation of the active sites available on adsorbent surface as a plant root surface.

Fig 9 (a) reveal the decolorization percentage of MB dye versus time. Maximum MB decolorization was observed in $10 \mathrm{mg} \mathrm{L}^{-1}$ after that, it reduces in 20, 30, 40 and $50 \mathrm{mg} \mathrm{L}^{-1}$. Fig 9 (b) predicts the decolorization of $\mathrm{CR}$ with time. After $24 \mathrm{~h}$ the concentration $10 \mathrm{mg} \mathrm{L}^{-1}$ and $20 \mathrm{mg} \mathrm{L}^{-1}$ follow same pattern of decolorization. Afterwards the percentage decolorization of $10 \mathrm{mg} \mathrm{L}^{-1}$ becomes high than 20,30, 40 and $50 \mathrm{mg} \mathrm{L}^{-1}$. Similar work was reported for removal of MB dye by using L. minor plant (Muhammad et al. 2019) and Chara vulgaris for the decolorization of the CR dye (Mahajan and Kaushal 2020).

The $\mathrm{pH}$ values of dyes solution have great effect on phytoremediation process for removing the dyes in their aqueous phase. In the current study, $\mathrm{pH}$ effect on $\mathrm{MB}$ and $\mathrm{CR}$ dyes remediation by $T$. ammi was projected by performing experiment from in the $\mathrm{pH}$ range 3 to 10 along with $20 \mathrm{mg} \mathrm{L}^{-1} \mathrm{MB}$ and $\mathrm{CR}$ dyes solutions. It was examined that both at high and low $\mathrm{pH}$, decolorization ability of plant get effected. The maximum decolorization 95.7\% is obtained at $\mathrm{pH} 8$ in case of $\mathrm{MB}$ dye by using $T$. ammi while with CR dye, maximum decolorization 97.3\% was observed at value of $\mathrm{pH} 5$ (Fig. 10). The $\mathrm{pH}$ of dye solution might be having large impact on the functional groups of dyes and the plant surface. The $\mathrm{pH}$ value above 8 , there was a sharp reduction in the 
effect of $\mathrm{pH}$ was documented in studies to remediate the acidic dyes in their aqueous state (Khataee et al. 2012). Therefore, the optimum value of $\mathrm{pH}$ for removal of MB and CR by $T$. ammi is at $\mathrm{pH}$ value 8 and 5 respectively.

\section{Mechanism of Phytoremediation of dyes by T. ammi}

257 Based on these result and discussions, a hypothetical mechanism is also proposed for phytoremediation of dyes

258

259

260

261

262

263

264

265

266

267

268

269

270

271

272

273

274

275

276

277

278

279

280

281

282 by T. ammi plant (Fig. 11). The roots of T. ammi plant plays an important role in removal of dyes from solution. The phytoabsorption of MB and CR dye by plant root has been confirmed through SEM studies of roots of $T$. ammi (Fig. 4). It has been clearly inferred the presence of phenolic and carboxyl functional groups in roots of $T$. ammi from FTIR results. Kinetic and equilibrium studies also indicate the the adsorption of dye occur on surface through chemical interaction of functional groups. Hence, it can be assumed that dye molecules get adsorbed through intermolecular H-bonding, electrostatic and aromatic $\pi-\pi$ interactions between functional group present on surface of roots of T. ammi and dye molecules as shown in Fig. 11. (Kaushal and Mahajan 2021). Once the dye gets phytoadsorbed on surface of roots then get assimilated inside the plant root cell where it gets detoxified by the internal mechanism of plant cell (Kabra et al. 2013). As the growth of T. ammi plant was not restricted and even rejuvenate after absortion of dye which implies that $T$. ammi plant has potential of remediate structurally different types of dyes. However, the future studies are required to explore mechanism for detoxification of dyes inside root cells.

\section{Cost effectiveness of the MB and CR removal through Phytoremediation}

Phytoremediation is the cost-effective solar driven technology in contrast with any-other physical, chemical, and biological processes (Khandare and Govindwar 2015). This technique provides the neutral and resourceful application to the removal of harmful pollutants out of the surrounding environment (Dietz and Schnoor 2008). Some of the physical and chemical processes which are reported for the removal of MB and CR dyes, need large amount of money for their operations. The oxidation method using the various catalysts proved to be a fast and effective method for removal of MB and CR dyes, but it involves high energy and large amount of chemical for its processing and that is the major limitation of the process (Tavares et al. 2012). The description of the results in current research work, proved the capacity of T. ammi to degrade the dyes MB and CR in natural forms without any additional chemicals. Therefore, the textile industrial area could implement the cost-effective and eco-friendly technology of phytoremediation by using ornamental plant for the treatment of the dye loaded wastewater ratherthan the using costly techniques for removal of the harmful dyes from the wastewater.

\section{Conclusion}

Phytoremediation studies were performed with T. ammi to remediate MB and CR dyes from the synthetic wastewater. The results of this research work indicated the capacity of $T$. ammi to treat the dyes wastewater for the water remediation methods. The various effect such as the influence of initial dye concentration, time and $\mathrm{pH}$ on the phytoremediation mechanism were observed. The decolorization potential of T. ammi toward MB and CR dye was decreased on increase in the initial dye concentration of these dye (10 to $50 \mathrm{mg} \mathrm{L}^{-1}$ ) while adsorption capacity found to be increased. The maximum decolorization MB and CR dye solution was found 99 and $85 \%$ respectively. The $\mathrm{pH}$ of dye solution also found to influences the phytoremediation process as $97 \%$ decolorization 
of $20 \mathrm{mg} \mathrm{L}^{-1} \mathrm{CR}$ dye observed at $\mathrm{pH} 5$ while $95 \%$ decolorization at $\mathrm{pH} 8$ for $\mathrm{MB}$. The maximum decolorization capacity by T. ammi explored its utilization for removal of the contaminants from the wastewater, especially dyes and can be grown in the dye contaminated area. The adsorption isotherms of Langmuir and Freundlich models investigate the adsorption pattern of $\mathrm{MB}$ and $\mathrm{CR}$ dyes on the T. ammi surface and Freundlich model found to be a little bit better fit for adsorption of both dyes $\mathrm{MB}\left(\mathrm{R}^{2} \geq 0.990\right)$ and $\mathrm{CR}\left(\mathrm{R}^{2} \geq 0.990\right)$ dye molecules on $T$. ammi root surface. The kinetic studies results supported the pseudo-first order kinetic model with the maximum correlation value $\mathrm{R}^{2} \geq 0.95$ and 0.97 for $\mathrm{MB}$ and $\mathrm{CR}$ respectively for phytoremediation by T. ammi. FTIR and SEM studies confirmed that dye molecules get phytoadsorbed by plant roots through the functional group interaction. After phytoadsortion, dye get finally assimilated inside the root cells where it gets detoxified. Future research work will plan to explore detoxification mechanism inside the plant cells. Hence, the observed outcomes suggested that the T. ammi is an efficient ornamental plant for phytoremediation of noxious dyes from the environment and can be utilized as an effective phytoremediator which provide sustainable solution for wastewater treatment in present scenario of environmental safety crisis.

\section{Declarations}

Competing interests: The authors declare that there is no competing interests.

Ethics approval and consent to participate: "Not applicable", as research does not report on or involve the use of any animal or human data or tissue.

Consent for publication: Not Applicable.

\section{Funding: No}

\section{Authors' contributions}

Navjeet Kaur: Conducted the experimental studies and drafted the manuscript; Jyotsna Kaushal: Conceptualization, expert view, data interpretation and overall Supervision; Pooja Mahajan: Data interpretation. All authors read and approved the final manuscript.

\section{Acknowledgements}

The authors express their gratitude to the Chitkara University, Rajpura for providing required lab facilities to complete this research work. 
Adki VS, Jadhav JP, Bapat VA (2012) Exploring the phytoremediation potential of cactus (Nopalea cochenillifera Salm. Dyck.) cell cultures for textile dye degradation. Int J Phytoremediation 14:554-569. https://doi.org/10.1080/15226514.2011.619226.

Ahmad A, Mohd-Setapar SH, Chuong CS, Khatoon A, Wani WA, Kumar R, Rafatullah M (2015) Recent advances in new generation dye removal technologies: novel search for approaches to reprocess wastewater. RSC Advances5:30801-30818. https://doi.org/10.1039/C4RA16959J

Al-Baldawi IA, Abdullah SRS, Almansoory AF, Ismail NI, Abu Hasan H, Anuar N (2020) Role of Salvinia molesta in biodecolorization of methyl orange dye from water. Sci Rep-UK. 10:13980. https://doi.org/10.1038/s41598-020-70740-5

Al-Baldawi IA, Abdullah SRS, Anuar N, Abu Hasan H (2018) Phytotransformation of methylene blue from water using aquatic plant (Azolla pinnata). Environ Technol Inno.11:15-22.

Ali N, Zada A, Zahid M, Ismail A, Rafiq M., Riaz A, Khan A 2019) Enhanced photodegradation of methylene blue with alkaline and transition-metal ferrite nanophotocatalysts under direct sun light irradiation. Chin Chem Soc 66(4): 402-408. https://doi.org/10.1002/jccs.201800213

Aljeboree AM, Alshirifi A.N, Alkaim A F (2017). Kinetics and equilibrium study for the adsorption of textile dyes on coconut shell activated carbon. Arab J of chem10: S3381-S3393. https://doi.org/1016/j.arabjc.2014.01.20

Arfin T, Sonawane K, Saidankar P, Sharma, S (2019) Role of microbes in the bioremediation of toxic dyes. Integ Green Chem and Sust Eng: 443-471.https://doi.org/10.4061/2011/805187

Chandanshive VV, Rane NR, Tamboli AS, Gholave AR, Khandare RV, Govindwar SP (2017) Co-plantation of aquatic macrophytes Typha angustifolia and Paspalumscrobiculatum for effective treatment of textile industry effluent. J Hazard Mater 338: 47-56. https://doi: 10.1016/j.jhazmat.2017.05.021

Dietz AC, Schnoor, JL (2001) Advances in phytoremediation. Environ Health Perspect 109 ( 1): 163 168. https://doi.org/10.2307/3434854

Ekanayake, MS, Udayanga, D, Wijesekara I. et al (2021) Phytoremediation of synthetic textile dyes: biosorption and enzymatic degradation involved in efficient dye decolorization by Eichhornia crassipes (Mart.) Solms and Pistia stratiotes L.. Environ Sci Pollut Res https://doi.org/10.1007/s11356-020-11699-8

Fytianos K, Voudrias E, Kokkalis E (2000) Sorption-desorption behavior of 2,4-dichlorophenol by fresh water sediments. Chemosphere 40: 3-6. https://doi.org/10.1016/S0045-6535(99)00214-3

Hameed BH, Din AM, Ahmad AL (2007) Adsorption of methylene blue onto bamboo-based activated carbon: kinetics and equilibrium studies. J Hazard Mater 141: 819-825. https://doi.org/10.1016/j.jhazmat.2006.07.049

https://doi.org/10.1155/2019/8351272

Imron MF, Kurniawan SB, Soegianto A. Wahyudianto FE (2019) Phytoremediation of MB using duckweed (Lemna minor). Heliyon, 5(8):1-5.http://doi.org/ 10.1016/j.heliyon.2019.e02206

Javed MT, Saleem MH, Aslam S, Rehman M, Iqbal N, Begum R, Ali S, Alsahli AA, Alyemeni MN, Wijaya L (2020) Elucidating silicon-mediated distinct morpho-physio-biochemical attributes and organic acid exudation patterns of cadmium stressed Ajwain (Trachyspermum ammi L.). Plant Physiol. Biochem 157: 2337. http://doi.org/10.1016/j.plaphy.2020.10.010

Kabra A, Khandare R, Kurade M, Govindwar S (2011 a) Phytoremediation of a sulphonated azo dye Green HE4B by Glandulariapulchella (Sweet) Tronc. (Moss Verbena). Environ Sci Pollut Res 18: 1360-1373. https://doi.org/10.1007/s11356-011-0491-7

Kabra AN, Khandare RV, Govindwar, SP (2013) Development of a bioreactor for remediation of textile effluent and dye mixture: a plant bacterial synergistic strategy. Water Res 47:1035-1048. https://doi.org/10.1016/j.watres.2012.11.007

Kagalkar AN, Jagtap UB, Jadhav JP, Bapat VA, Govindwar SP (2009) Biotechnological strategies for phytoremediation of the sulfonated azo dye Direct Red 5B using Blumea malcolmii Hook. BioresourTechnol100:4104-10. https://doi.org/10.1016/j.biortech.2009.03.049

Kang YG, Yoon H, Lee CS, Kim EJ, Chang YS (2019) Advanced oxidation and adsorptive bubble separation of dyes using MnO2-coated Fe3O4 nanocomposite. Water Res151:413-22. https://doi.org/10.1016/j.watres.2018.12.038 
Kaur S, Rani S, Mahajan RK, Asif M, Gupta VK (2015) Synthesis and adsorption properties of mesoporous material for the removal of dye safranin: kinetics, equilibrium, and thermodynamics. J of Indus and Eng Chem 22:19-27. https://doi.org/10.1016/j.jiec.2014.06.019

Kaushal J, Mahajan P (2015) Exploring the Phytoremediation Potential of Salvinia molesta for the degradation of Malachite green dye. Res J Chem Environ19:1-8. https://doi.org/10.1007/s00128-021-03297-2

Kaushal J, Mahajan P (2021). Kinetic Evaluation for Removal of an Anionic Diazo Direct Red 28 by Using Phytoremediation Potential of Salvinia molesta Mitchell. Bull Environ Contam Toxicol. https://doi.org/10.1007/s00128-021-03297-2

Khandare RV, Kabra AN, Kurade MB, Govindwar SP (2011a) Phytoremediation potential of Portulaca grandiflora Hook.(Moss-Rose) in degrading a sulfonated diazo reactive dye Navy Blue HE2R (Reactive Blue 172). Biores technol 102(12):6774-7. https://doi.org/10.1016/j.biortech.2011.03.094

Khandare RV, Kabra AN, Tamboli DP, Govindwar, SP (2011b) The role of Aster amelluslinn in degradation of a sulfonated azo dye remazol red A Phytoremediation strategy. Chemosphere 82(8): 1147-1154. http://doi.org/10.1016/j.chemosphere.2010.12.073

Khandare RV, Govindwar SP (2015) Phytoremediation of textile dyes and effluents: Current scenario and future prospects. Biotechnol Adv 33(8): 1697-1714.https://doi: 10.1016/j.biotechadv.2015.09.003

Khataee AR, Movafeghi A, Torbati S, Salehi, Lisar, S.Y, Zarei M (2012) Phytoremediation potential of duckweed (Lemna minor L.) in degradation of CI Acid Blue 92: artificial neural network modeling. Ecotox Environ Safe, 80: 291-298. https://doi.org/10.1016/j.ecoenv.2012.03.021

Konicki W, Sibera D, Mijowska E, Lendzion-Bieluń Z, Narkiewicz U (2013) Equilibrium and kinetic studies on acid dye Acid Red 88 adsorption by magnetic ZnFe2O4 Spinel Ferrite nanoparticles. J of colloid and interface Sci 398:152-160.https://doi: 10.1016/j.jcis.2013.02.021

Leggett JE, Frere MH (1971) Growth and nutrient uptake by soybean plants in nutrient solutions of graded concentrations. Plant Physiol, 48(4), pp.457-460. https://doi.org/10.1104/pp.48.4.457

Mahajan P, Kaushal J (2019) Phytoremediation of carcinogenic diazo Congo Red dye by using Pistia stratiotes (water lettuce). Res J Chem Environ 23: 65-73.

Mahajan P, Kaushal J (2020) Phytoremediation of azo dye methyl red by macroalgae Chara vulgaris L.: kinetic and equilibrium studies. Environ Sci and Pollu Res: 1-13. https://doi.org/10.1007/s11356-020-08977-w.

Mahajan P, Kaushal J, Upmanyu A, Bhatti J (2019) Assessment of phytoremediation potential of Chara vulgaris to treat toxic pollutants of textile effluent. J Toxicol-US: 8351272.

Mahmoudabadi TZ, Talebi P, Jalili M (2019) Removing disperse red 60 and reactive blue 19 dyes removal by using Alcea rosea root mucilage as natural coagulant. AMB Express 9(1): 1-8. http://doi.org/10.1186/s13568019-0839-9

Mi-Hwa B, Ijagbemi BCO, Se-Jin O, Kim DS (2010) Removal of Malachite green from aqueous solution using degreased coffee bean. J Hazard Mater 176: 820-828. https://doi.org/10.1016/j.jhazmat.2009.11.110

Mosoarca G, Vancea C, Popa S and Boran S (2018) Adsorption, bioaccumulation and kinetics parameters of the phytoremediation of cobalt from wastewater using Elodea canadensis. Bull Environ Contam Toxicol., 100 :733-739.

Nilratnisakorn S, Thiravetyan P, Nakbanpote W (2007) Synthetic reactive dye wastewater treatment by narrowleaved cattails (Typha angustifolia Linn.): effects of dye, salinity and metals. Sci Total Environ 384: 67-76. https://doi.org/10.1016/j.scitotenv.2007.06.027

Qamar N, John P, Bhatti A (2020). Toxicological and Anti-Rheumatic Potential of Trachyspermum ammi Derived Biogenic Selenium Nanoparticles in Arthritic Balb/c Mice. Int J of Nanomed 15: 3497-3509. https://doi.org/10.2147/IJN.S243718.

Revathi H, Subalakshmi K, Ahamed, JS, Kaviyarasu A, Murugan T. Kumar M.D (2018) Adsorption Studies onto Grey BL dye using the leaves of Trachyspermum ammi (Ajwain Leaves). http://dx.doi.org/10.20902/IJCTR.2018.110819.

Saber S, Mahmoud AA, Goda R, Helal N S, El-ahwany, E. Abdelghany R.H (2018) Perindopril, fosinopril and losartan inhibited the progression of diethylnitrosamine-induced hepatocellular carcinoma in mice via the inactivation of nuclear transcription factor kappa-B. Toxicol letters 295: 32-40. https://doi.org/10.1016/j.toxlet.2018.05.036Get. 
Sánchez-Galván G, Monroy O, Gómez J, Olguín E J (2008) Assessment of the hyperaccumulating lead capacity of Salvinia minima using bioadsorption and intracellular accumulation factors. Water Air Soil Poll 194: 7790. https://doi.org/10.1007/s11270-008-9700-5

Sarkar, S, Banerjee A, Halder U, Biswas R, Bandopadhyay R (2017). Degradation of synthetic azo dyes of textile industry: a sustainable approach using microbial enzymes. Water Conser Sci and Eng 2(4): 121-131. https://doi.org/10.1007/s41101-017-0031-5

Sharma R, Saini H, Paul DR, et al (2021) Removal of organic dyes from wastewater using Eichhornia crassipes: a potential phytoremediation option. Environ Sci Pollut Res 28: 7116-7122 https://doi.org/10.1007/s11356020-10940-8

Shanmugam L, Ahire M, Nikam T (2020) Bacopa monnieri (L.) Pennell, a potential plant species for degradation of textile azo dyes. Environ Sci and Pollu Res, 27:9349-9363. https://doi.org/10.1007/s11356-019-07430-x

Tan KA, Morad N, Ooi JQ (2016) Phytoremediation of methylene blue and methyl orange using Eichhornia crassipes. Int J Environ Sci Develop : 724-728. https://doi: 10.18178/ijesd.2016.7.10.869

Tavares MG, Da Silva LV, Solano A M, Tonholo J, Martínez-Huitle CA, Zanta CL (2012) Electrochemical oxidation of methyl red using Ti/Ru0. 3Ti0. $7 \mathrm{O}_{2}$ and $\mathrm{Ti} / \mathrm{Pt}$ anodes. Chem Eng J 204: 141-150. https://doi.org/10.1016/j.cej.2012.07.056.

Ullah A, Farooq M, Nadeem F, Rehman A, Hussain M, Nawaz A, Naveed M, (2020). Zinc application in combination with zinc solubilizing Enterobacter sp. MN17 improved productivity, profitability, zinc efficiency, and quality of desi chickpea. J of Soil Science and Plant Nutrition 20(4): 2133-2144. https://doi.org/10.1007/s42729-020-00281-3

Wang X, Shan T, Pang S (2018). Phytoremediation potential of Saccharina japonica and Sargassum horneri (Phaeophyceae): biosorption study of strontium. Bulletin of Environ Cont and toxicol 101(4): 501-505. https:// doi.10.1007/s00128-018-2435-0 
Table1. Comparative analysis of FTIR peaks of T. ammi roots before and after adsorption of Methylene Blue and

\begin{tabular}{|c|c|c|c|c|c|}
\hline \multirow{2}{*}{$\begin{array}{l}\text { S. } \\
\text { No. }\end{array}$} & \multicolumn{3}{|c|}{$\begin{array}{c}\text { Peak position }\left(\mathrm{cm}^{-1}\right) \text { in FTIR spectra of } T \text {. ammi } \\
\text { roots }\end{array}$} & \multirow{2}{*}{$\begin{array}{l}\text { Functional group } \\
\text { assigned }\end{array}$} & \multirow{2}{*}{ Intensity } \\
\hline & $\begin{array}{l}\text { Before dye } \\
\text { adsorption }\end{array}$ & $\begin{array}{l}\text { After MB } \\
\text { adsorption }\end{array}$ & $\begin{array}{l}\text { After CR } \\
\text { adsorption }\end{array}$ & & \\
\hline 1 & 3431.0 & 3466.4 & 3371.4 & $\begin{array}{l}\text { O-H (hydroxyl group } \\
\text { stretch) }\end{array}$ & Strong, broad \\
\hline 2 & $2926.0-2851.4$ & $2926.0-2855.1$ & 2920.4-2851.4 & $\begin{array}{l}-\mathrm{CH}_{2-} \text { (methylene group } \\
\text { stretching) }\end{array}$ & Medium \\
\hline 3 & 2374.3 & ---- & 2316.5 & $\begin{array}{l}\mathrm{O}=\mathrm{C}=\mathrm{O} \text { (carboxyl group } \\
\text { stretch) }\end{array}$ & Medium \\
\hline 4 & 1699.0 & ---- & ----- & $\begin{array}{l}-\mathrm{C}=\mathrm{O} \text { (Non-conjugated } \\
\text { stretch) }\end{array}$ & Strong \\
\hline 5 & ---- & ---- & 1653.1 & $\begin{array}{l}\mathrm{N}-\mathrm{H} \text { bending (amide } \\
\text { interaction) }\end{array}$ & Medium, broad \\
\hline 6 & --- & 1584.1 & ------ & $\begin{array}{l}-\mathrm{C}=\mathrm{O}(\text { Conjugated } \\
\text { stretch) }\end{array}$ & Medium \\
\hline 7 & --- & 1509.6 & 1507.7 & $\begin{array}{l}\text { C-C stretching (aromatic } \\
\text { group) }\end{array}$ & Weak \\
\hline 8 & 1490.9 & ---- & ----- & $\begin{array}{l}\mathrm{C}=\mathrm{C} \text { stretching } \\
\text { (aromatic) }\end{array}$ & Medium \\
\hline 9 & & 1451.8 & 1418.3 & C-O stretching & Weak \\
\hline 10 & 1343.7 & 1323.2 & 1321.3 & $\mathrm{O}-\mathrm{H}$ bending (phenol) & $\begin{array}{l}\text { Medium, Weak, } \\
\text { weak }\end{array}$ \\
\hline 11 & 1248.7 & 1233.7 & 1261.7 & C-O (carbonyl) & $\begin{array}{l}\text { Medium, Medium, } \\
\text { Weak }\end{array}$ \\
\hline 12 & 1183.4 & 1187.2 & 1156.5 & C-O stretch (alcohol) & Weak \\
\hline 13 & 1036.2 & 1058.6 & 1034.3 & C-N stretching & $\begin{array}{l}\text { Weak, medium, } \\
\text { medium }\end{array}$ \\
\hline 14 & 950.5 & ---- & & $=\mathrm{C}-\mathrm{H}$ (alkene) & Medium \\
\hline
\end{tabular}


Table 2. Kinetic model constant values for phytoremediation of Methylene Blue dye by T. ammi.

\begin{tabular}{|c|c|c|c|c|c|c|}
\hline \multirow{2}{*}{ Kinetic Model } & \multirow{2}{*}{ Kinetic Parameters } & \multicolumn{5}{|c|}{ Initial dye concentration $\mathrm{mg} \mathrm{L}^{-1}$} \\
\hline & & 10 & 20 & 30 & 40 & $\mathbf{5 0}$ \\
\hline \multirow{5}{*}{$\begin{array}{l}\text { Pseudo-First } \\
\text { Order }\end{array}$} & $\mathrm{q}_{\mathrm{e}(\exp )}\left(\mathrm{mg} \mathrm{g}^{-1}\right)$ & 0.049 & 0.085 & 0.105 & 0.124 & 0.135 \\
\hline & $\mathrm{K}_{1}$ & 0.030 & 0.022 & 0.026 & 0.017 & 0.022 \\
\hline & $\mathrm{q}_{\mathrm{e} \text { (theor) }}\left(\mathrm{mg} \mathrm{g}^{-1}\right)$ & 0.056 & 0.091 & 0.116 & 0.125 & 0.140 \\
\hline & $R_{1}^{2}$ & 0.887 & 0.943 & 0.904 & 0.951 & 0.881 \\
\hline & $\Delta \mathrm{q}_{\mathrm{t} 1}(\%)$ & 0.432 & 0.241 & 0.168 & 0.143 & 0.112 \\
\hline \multirow{4}{*}{$\begin{array}{l}\text { Pseudo-Second } \\
\text { Order }\end{array}$} & $\mathrm{q}_{\mathrm{e} 2 \text { (theor) }}\left(\mathrm{mg} \mathrm{g}^{-1}\right)$ & 0.086 & 0.179 & 0.202 & 0.232 & 0.244 \\
\hline & $\mathrm{K}_{2}$ & 11.5 & 5.57 & 4.93 & 4.33 & 4.08 \\
\hline & $\mathrm{R}_{2}^{2}$ & 0.844 & 0.780 & 0.847 & 0.915 & 0.933 \\
\hline & $\Delta \mathrm{q}_{12}(\%)$ & 2.85 & 2.14 & 1.85 & 0.94 & 0.87 \\
\hline \multirow{5}{*}{$\begin{array}{l}\text { Elovinch } \\
\text { Equation }\end{array}$} & $\mathrm{q}_{\mathrm{e} 3 \text { (theor) }}\left(\mathrm{mg} \mathrm{g}^{-1}\right)$ & 0.729 & 1.313 & 1.613 & 2.654 & 1.952 \\
\hline & $\alpha$ & 0.005 & 0.008 & 0.011 & 0.014 & 0.014 \\
\hline & $\beta$ & 53.1 & 29.41 & 23.98 & 14.47 & 19.84 \\
\hline & $\mathrm{R}_{3}^{2}$ & 0.912 & 0.909 & 0.929 & 0.637 & 0.854 \\
\hline & $\Delta \mathrm{q}_{13}(\%)$ & 16.55 & 16.02 & 14.43 & 14.21 & 14.14 \\
\hline
\end{tabular}

498

499

500

501

502

503

504

505

506

507

508

509 
511 Table 3. Kinetic model constant values for phytoremediation of Congo Red (CR) dye by T. ammi

\begin{tabular}{|c|c|c|c|c|c|c|}
\hline \multirow{2}{*}{ Kinetic Model } & \multirow{2}{*}{ Kinetic Parameters } & \multicolumn{5}{|c|}{ Initial dye concentration $\mathrm{mg} \mathrm{L}^{-1}$} \\
\hline & & 10 & 20 & 30 & 40 & 50 \\
\hline \multirow{5}{*}{$\begin{array}{l}\text { Pseudo First } \\
\text { Order }\end{array}$} & $\mathrm{q}_{\mathrm{e}(\exp )}\left(\mathrm{mg} \mathrm{g}^{-1}\right)$ & 0.0473 & 0.084 & 0.1105 & 0.1315 & 0.1512 \\
\hline & $\mathrm{K}_{1}$ & 0.028 & 0.015 & 0.018 & 0.043 & 0.020 \\
\hline & $\mathrm{q}_{\mathrm{e} \text { (theor) }}\left(\mathrm{mg} \mathrm{g}^{-1}\right)$ & 0.0516 & 0.0709 & 0.0958 & 0.1244 & 0.1349 \\
\hline & $\mathrm{R}_{1}^{2}$ & 0.9718 & 0.909 & 0.9509 & 0.9676 & 0.9785 \\
\hline & $\Delta \mathrm{q}_{\mathrm{t} 1}(\%)$ & 0.445 & 0.267 & 0.156 & 0.142 & 0.125 \\
\hline \multirow{4}{*}{$\begin{array}{l}\text { Pseudo } \\
\text { Order }\end{array}$} & $\mathrm{q}_{\mathrm{e} 2 \text { (theor }}\left(\mathrm{mg} \mathrm{g}^{-1}\right)$ & 0.0533 & 0.1074 & 0.1444 & 0.1677 & 0.2015 \\
\hline & $\mathrm{K}_{2}$ & 13.73 & 9.30 & 6.90 & 5.96 & 4.96 \\
\hline & $\mathrm{R}_{2}^{2}$ & 0.684 & 0.790 & 0.873 & 0.929 & 0.931 \\
\hline & $\Delta \mathrm{q}_{\mathrm{t} 2}(\%)$ & 2.74 & 2.12 & 1.94 & 0.97 & 0.79 \\
\hline \multirow{5}{*}{$\begin{array}{l}\text { Elovinch } \\
\text { Equation }\end{array}$} & $\mathrm{q}_{\mathrm{e} 3 \text { (theor }}\left(\mathrm{mg} \mathrm{g}^{-1}\right)$ & 0.5874 & 0.9037 & 1.2351 & 1.4383 & 1.8139 \\
\hline & $\alpha$ & 0.00702 & 0.01338 & 0.01824 & 0.0248 & 0.02484 \\
\hline & $\beta$ & 65.78 & 43.66 & 31.94 & 27.54 & 22.42 \\
\hline & $\mathrm{R}_{3}^{2}$ & 0.747 & 0.745 & 0.839 & 0.896 & 0.914 \\
\hline & $\Delta \mathrm{q}_{\mathrm{t} 3}(\%)$ & 16.25 & 16.14 & 14.41 & 14.13 & 14.02 \\
\hline
\end{tabular}


531 Table 4. Langmuir and Freundlich constants for Phytoremediation of Methylene Blue (MB) and Congo Red (CR)

\begin{tabular}{cccc}
\hline Equilibrium Model & Constants & MB & CR \\
\hline \multirow{2}{*}{ Langmuir Isotherm } & $\mathrm{Q}_{0}\left(\mathrm{mg} \mathrm{g}^{-1}\right)$ & 0.138 & 0.162 \\
& $\mathrm{~b}\left(\mathrm{mg} \mathrm{g}^{-1}\right)$ & 0.700 & 0.388 \\
& $\mathrm{R}^{2}$ & 0.987 & 0.983 \\
\hline \multirow{2}{*}{ Freundlich isotherm } & $1 / \mathrm{n}$ & 0.1784 & 0.3175 \\
& $\mathrm{~K}_{\mathrm{F}}$ & 0.0745 & 0.0576 \\
& $\mathrm{R}^{2}$ & 0.990 & 0.999
\end{tabular}

532

533

534

535

536

537

538

539

540

541

542

543

544

545

546

547

548

549

550

551

552

553

554

555 


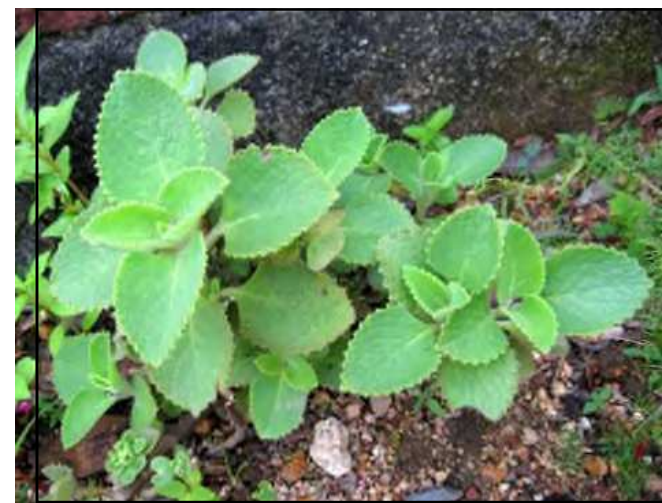<smiles>CN(C)c1ccc2nc3ccc(=[N+](C)C)cc-3sc2c1</smiles>

(a)

(b)

Fig. 1 Chemical Structure of (a) Congo red (CR) (b) Methylene blue (MB)

Fig. 2 Image and Classification of Trachyspermum ammi

Kingdom: Plantae

Divison: Magnoliophyta

Class: Magnoliopsida

Order: Apiales

Family: Apiaceae

Genus: Trachyspermum

Species: Trachyspermum ammi (L.)

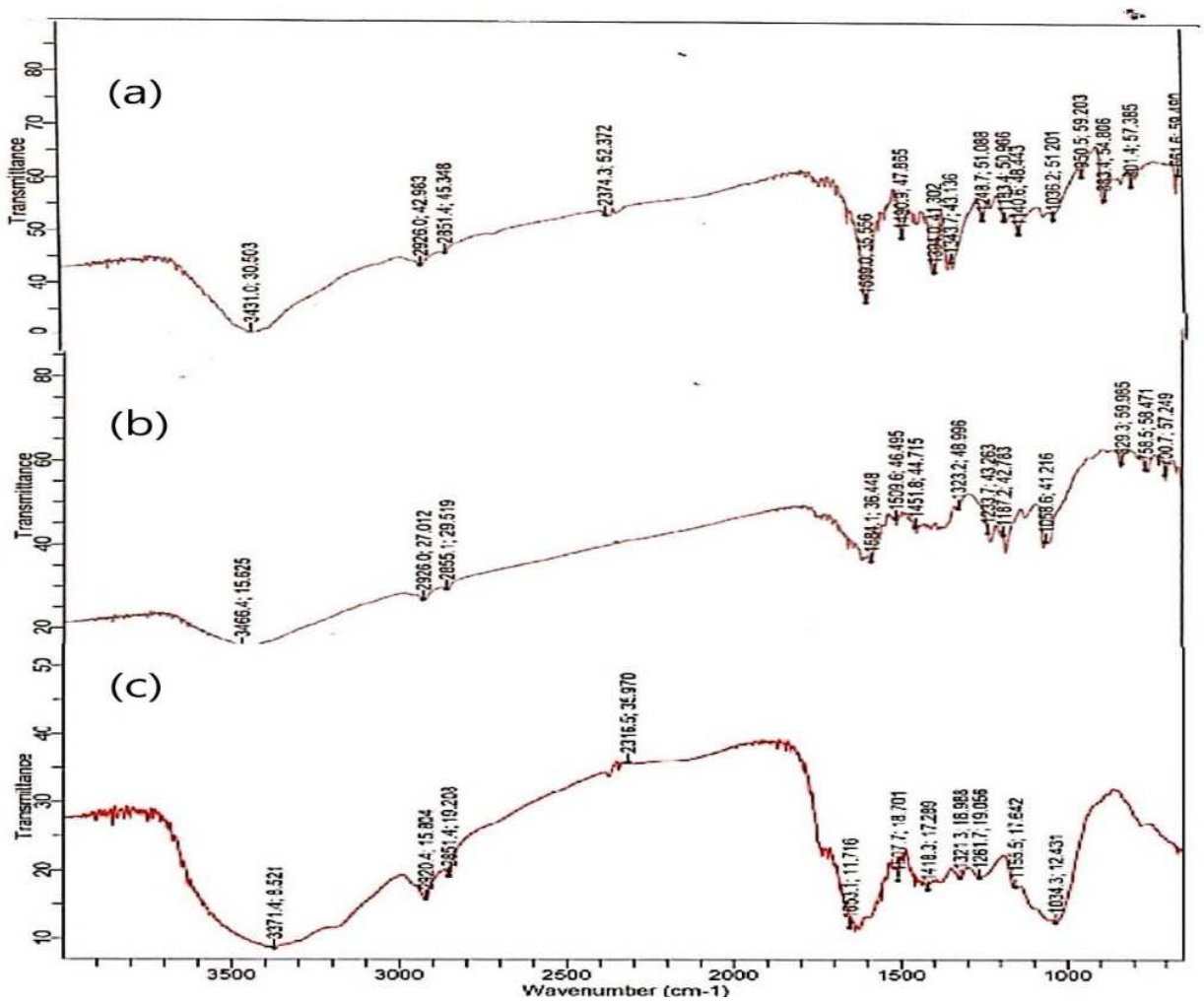

Fig 3. IR spectra of T. ammi roots before and after MB dye adsorption 


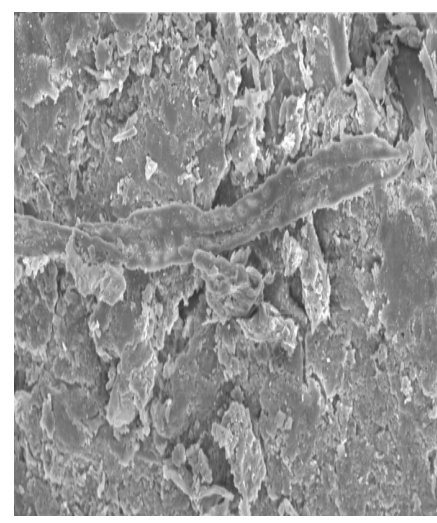

(a)

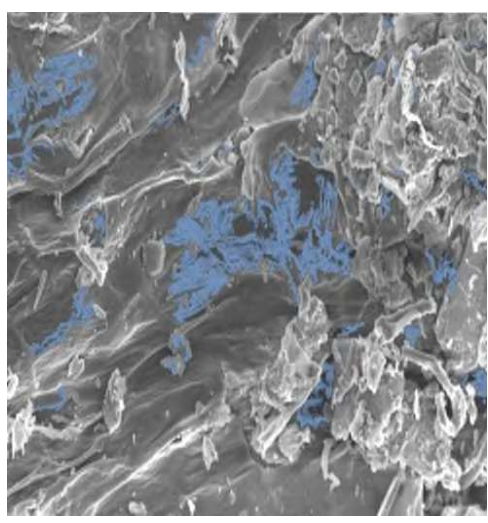

(b)

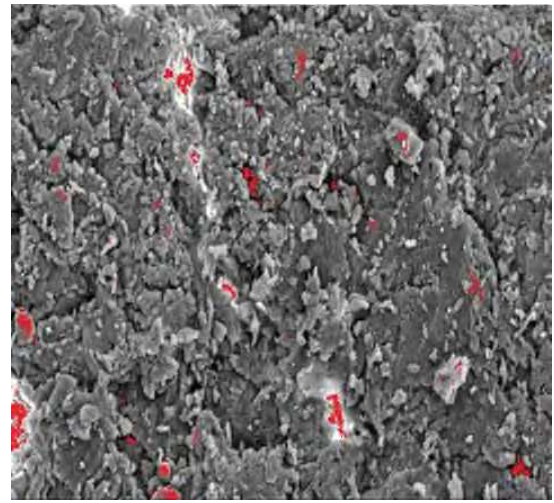

(c)

572 Fig. 4 SEM of T. ammi roots (a) Before phytoremediation (b) After phytoremediation of MB (c) After 573 phytoremediation of CR dye

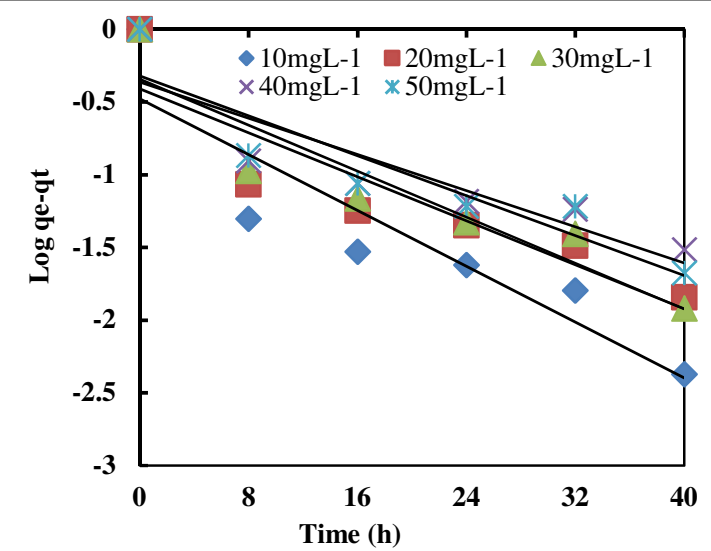

(a)

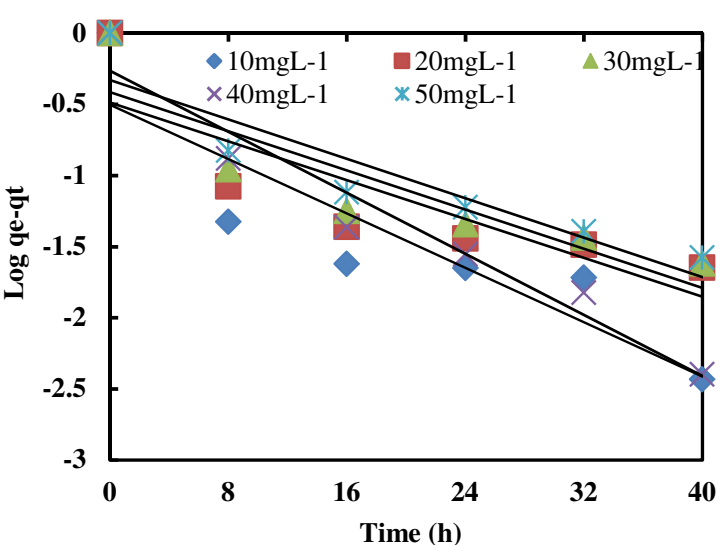

(b)

Fig. 5 Pseudo first order kinetic model for (a) Methylene blue (b) Congo red dye 

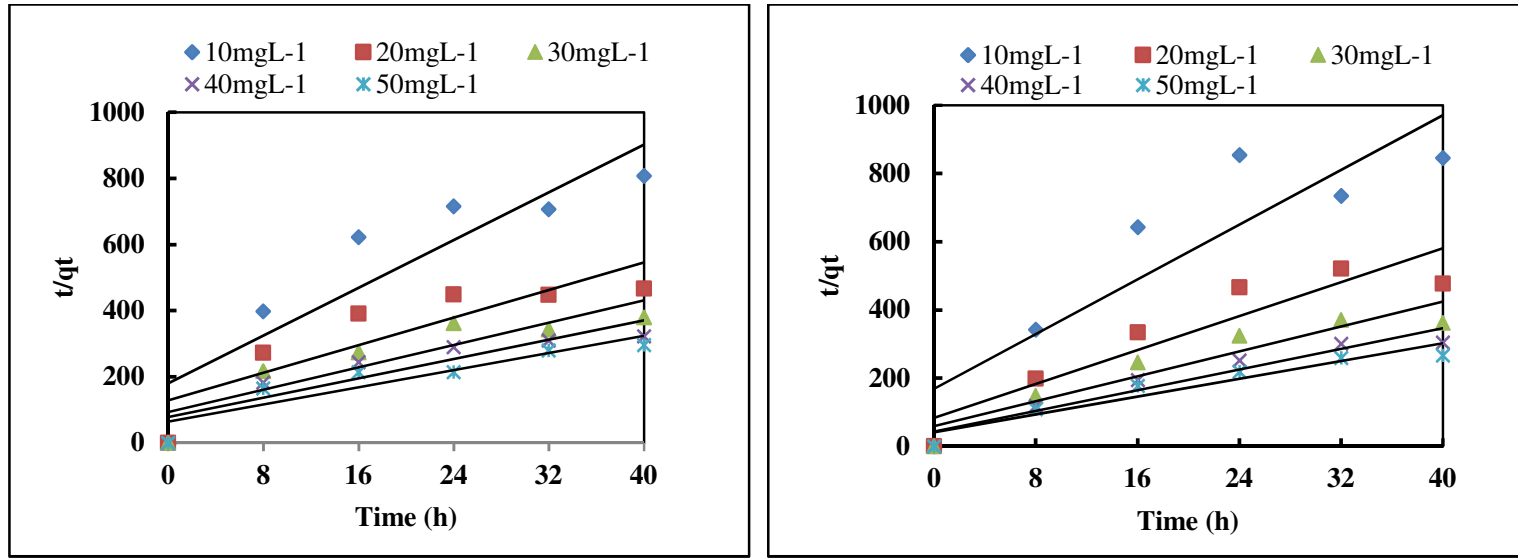

Fig. 6 Pseudo second order kinetic model for (a) Methylene blue (b) Congo red dye phytoremediation by $T$. ammi

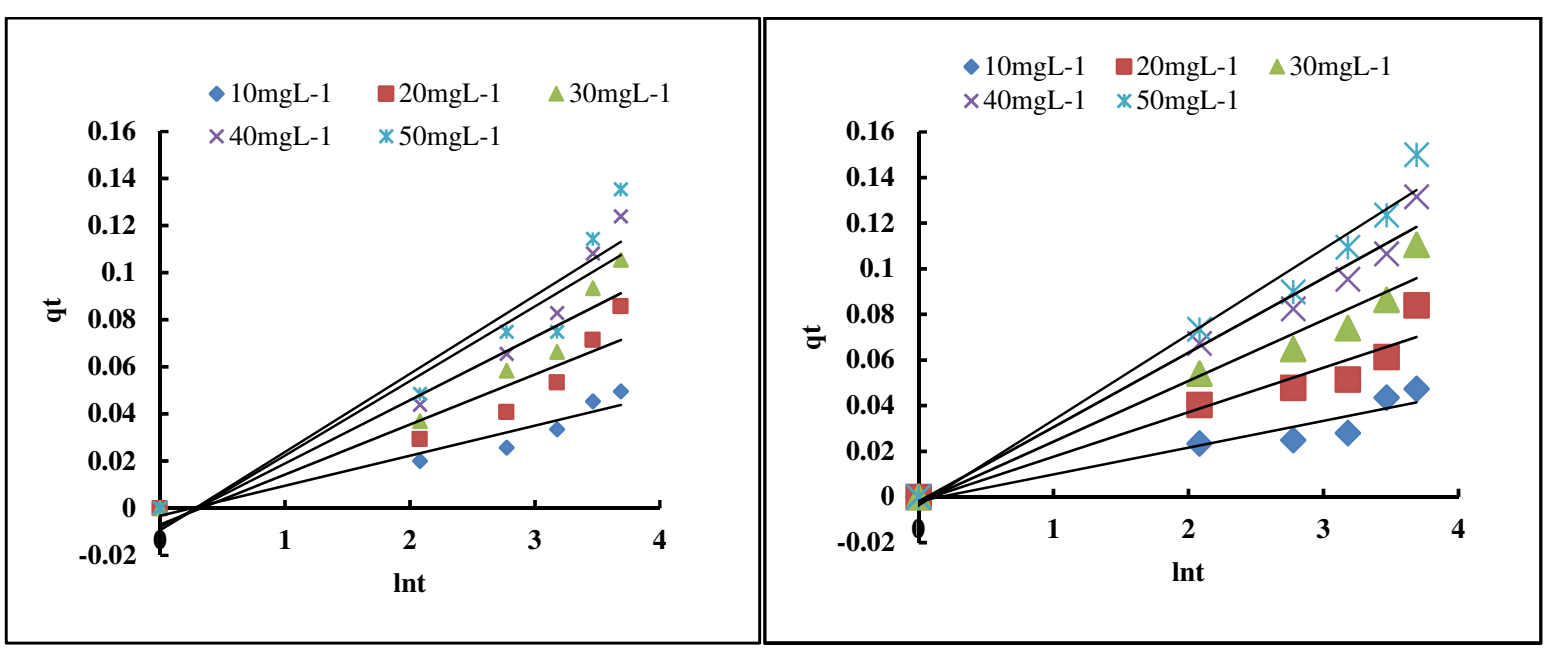

Fig. 7 Elovinch equation kinetic model for (a) Methylene blue (b) Congo red dye phytoremediation by T. ammi 


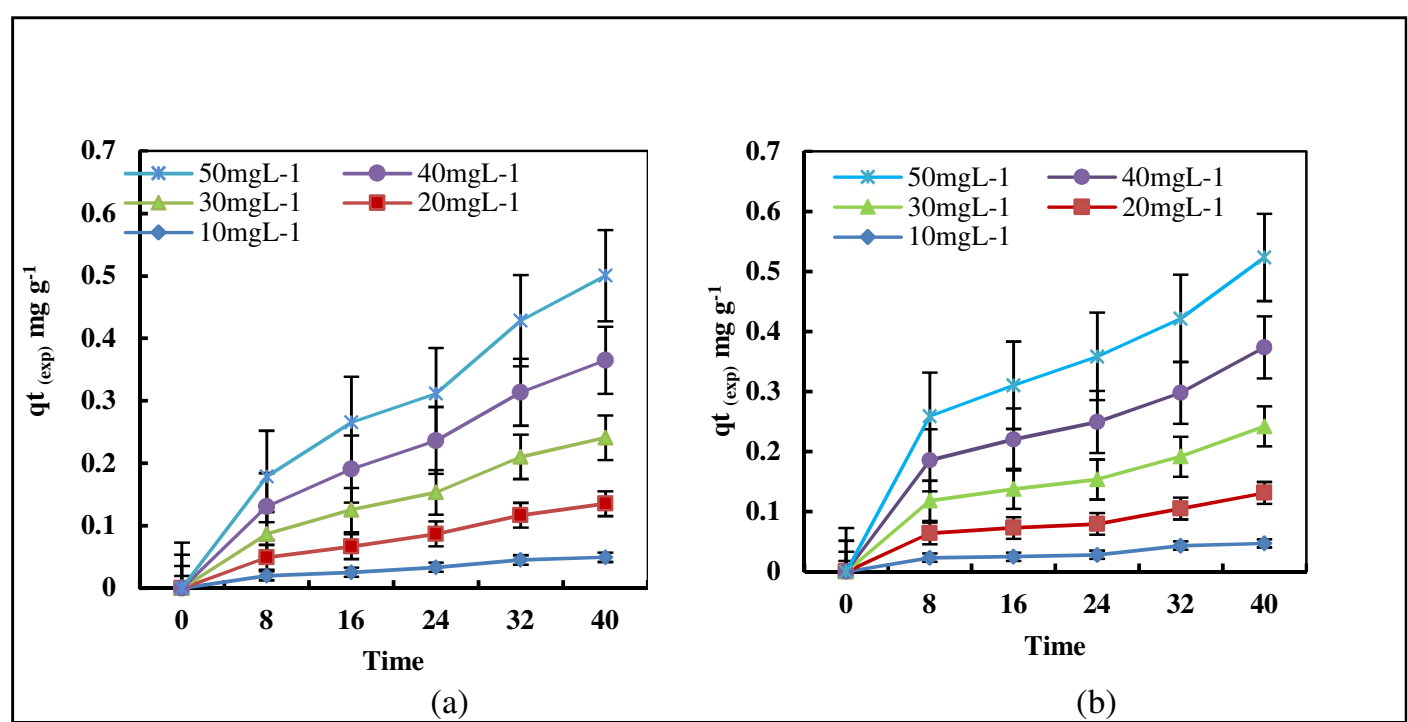

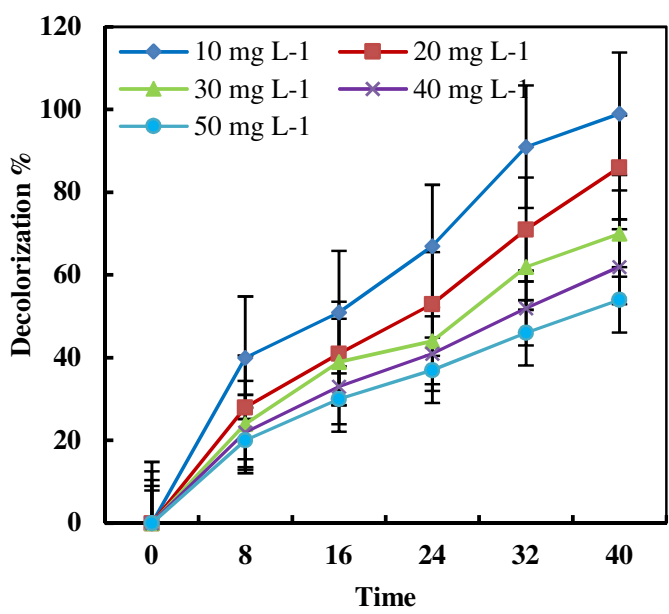

(a)

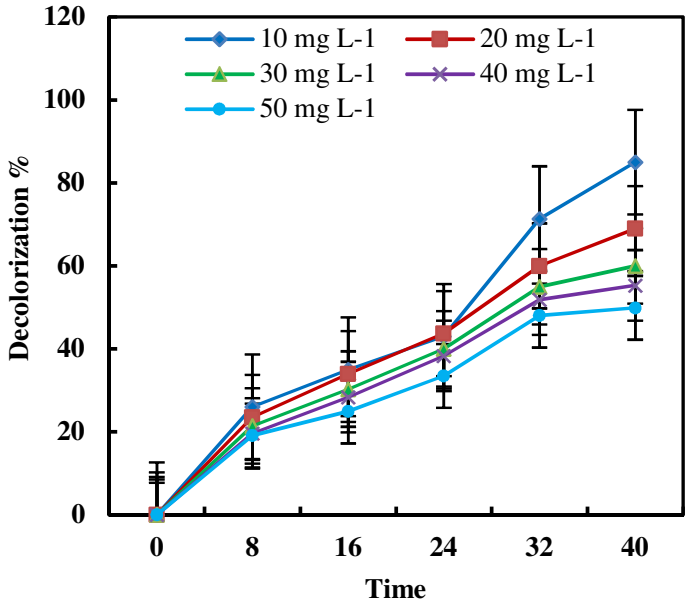

(b)

Fig. 9 Decolorization variation of (a) Methylene blue and (b) Congo Red dye by T. ammi with time 


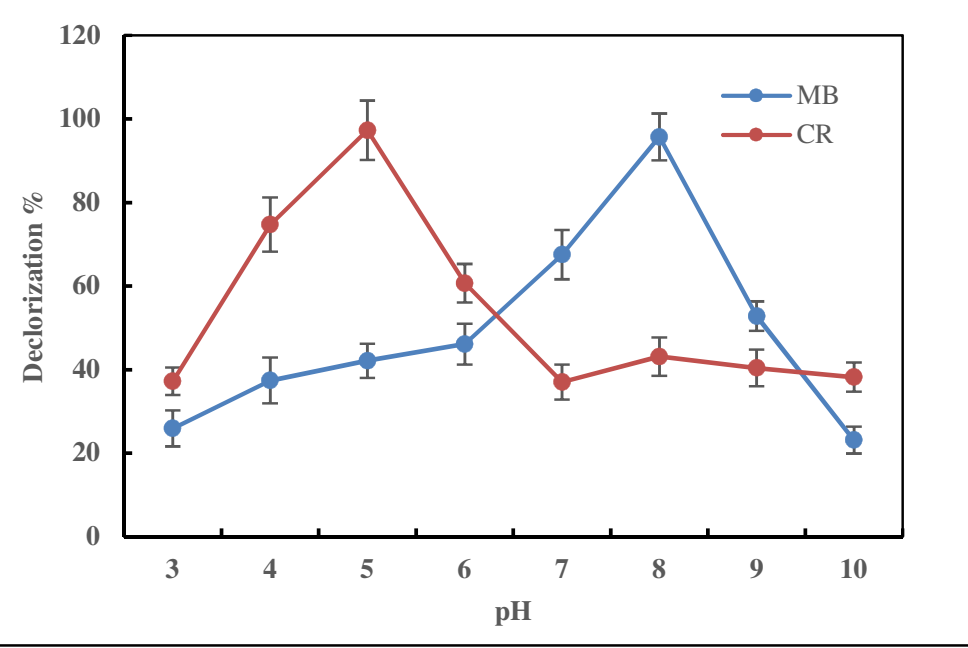

Fig. 10 Effect of $\mathrm{pH}$ on decolorization pattern of T. ammi for MB and CR

Fig. 11 Proposed Mechanism for Phytoadsorption of Methylene Blue (MB) and Congo Red (CR) 